\title{
APLIKASI TEKNOLOGI PENGADAAN AIR BERSIH DI EMPAT DESA TERTINGGAL DI BENGKULU SELATAN
}

\author{
Oleh : \\ P. Nugro Rahardjo \\ Peneliti pada Pusat Teknologi Lingkungan, BPPT
}

\begin{abstract}
In County South Bengkulu there are 4 villages classified into poor villages. Those villages do not have some principal facilities yet, such as clean water supply system and electricity. To fulfill clean water need, the people use shallow groundwater which has very bad quality. The groundwater contains Fe $(1.7 \mathrm{ppm})$ and $\mathrm{Mn}(0.7 \mathrm{ppm})$. The contents are much more than the standard quality allowed by WHO. The groundwater colour is also a little bit brown. To deal with those problems, BPPT (Agency for the Assessment and Application of Technology) has tried to apply a water treatment system which is supported by a solar cell system producing the electricity. The electric energy is used for pumping the groundwater. The water treatment has a mainly important process which is accommodated in a multy media filter. The media include coarse coral, find coral, sand silica, manganese zeolite and activated carbon. The media filter can reduce the contaminants ( $\mathrm{Fe} \& \mathrm{Mn}$ ) and remove the odour effectively. The complete water treatment system has been applied successfully in the 4 villages (one for each village).
\end{abstract}

Keywords : Clean Water Supply Technology.

\section{PENDAHULUAN}

\section{$1.1 \quad$ Latar Belakang}

Di seluruh Indonesia masih sangat banyak desa-desa yang tergolong tertinggal atau dapat dikatakan miskin. Salah satu kriteria penggolongan yang digunakan untuk menentukan suatu desa atau suatu komunitas masyarakat tertentu miskin atau tertinggal adalah apabila kebutuhan air bersihnya tidak terpenuhi. Kabupaten Bengkulu Selatan juga merupakan satu kabupaten yang masih memiliki banyak desa tertinggal, empat diantaranya adalah Desa Talang Alay, Desa Padang Kuas, Desa Tebat Gunung dan Desa Maras Jauh. Masyarakat di keempat desa ini umumnya bekerja sebagai buruh tani atau buruh perkebunan. Namun karena para kepala rumah tangga hanya berpenghasilan sesuai UMR ( \pm Rp. 800.000,perbulan) dan di desanya juga belum ada fasilitas yang memadai untuk penyediaan air bersih dan energi listrik, maka masyarakat di empat desa tersebut hidup sangat memprihatinkan.

$\mathrm{Di}$ wilayah Bengkulu Selatan, pada umumnya masyarakat menggunakan air tanah dangkal sebagai sumber air bersihnya untuk keperluan sehari-hari. Dengan cara membuat sumur gali yang sangat sederhana di sekitar halaman rumahnya, maka penduduk merasa bahwa kebutuhan air bersihnya sudah terpenuhi. Namun hampir seluruh sumur penduduk belum menggunakan cincin sumur, sehingga air sumurnya mudah terkontaminasi oleh tanah dan lingkungan sekitarnya. Disamping itu kapasitas air tanah ini sangat dipengaruhi oleh adanya air hujan, sehingga pada musim kemarau permukaan air tanah akan turun. Oleh karena itu bagi penduduk yang kedalaman sumurnya hanya 2 - 4 meter, pada musim kemarau panjang resikonya sangat tinggi, yaitu kemungkinan sumurnya akan kering. Dalam keadaan seperti ini biasanya penduduk menggunakan air sungai untuk keperluan sehari-harinya. Bila sumur gali mempunyai kedalaman lebih dari 4 meter, maka air tanahnya akan berkualitas sangat buruk, yaitu berbau dan mengandung besi, serta mangan yang cukup tinggi. Jadi air tanah tersebut berwarna kuning-kecoklatan. Dalam keadaan terpaksa, maka sebagian penduduk terpaksa menggunakan air tanah tersebut untuk memenuhi kebutuhan air bersihnya sehari-hari.

\subsection{Tujuan}

Tujuan dari pelaksanaan penelitian ini adalah mengaplikasikan suatu teknologi pengadaan air bersih yang sesuai dengan kondisi setempat dan selanjutnya diharapkan dapat meningkatkan kondisi kesehatan masyarakat, khususnya di empat desa tertinggal tersebut (Desa Talang Alay, Desa Padang Kuas, Desa Tebat Gunung dan Desa Maras Jauh). Karema itu teknologi pengolahan air yang diterapkan adalah teknologi pengolahan air sistem saringan yang merupakan suatu alat 
penjernih air yang sederhana, baik dalam pengoperasian maupun dalam perawatannya dan dalam prosesnya tidak memerlukan zat kimia. Sistem ini disesuaikan dengan kondisi sosial dan ekonomi masyarakat setempat.

\section{CARA MENGATASI MASALAH PEMENUHAN KEBUTUHAN AIR BERSIH}

\subsection{Kondisi Desa dan Masyarakatnya}

Kondisi keempat desa miskin yang memperoleh bantuan teknis dari Tim BPPT pada umumnya sangat berat, khususnya dalam hal ketiadaan penyediaan air bersih dan ketiadaan fasilitas jaringan/penyediaan listrik. Energi listrik hanya diperoleh dari adanya mesin diesel pembangkit listrik dengan kapasitas sekitar 10 KVA yang berada di Kantor Kepala Desa. Namun karena ketiadaan dana rutin dari Pemerintah Daerah, maka kebutuhan BBM (solar) tidak dapat terpenuhi lagi. Mesin pembangkit listrik hanya digunakan untuk acara atau kegiatan insidentil, seperti bila ada kunjungan Camat atau Bupati kepala daerah. Karena itu unit atau sistem pengolahan air ditempatkan di kantor atau balai desa. Hal ini dimaksudkan agar perangkat desa atau masyarakat yang berniat membuat sistem pengolahan air sendiri atau untuk kepentingan bersama dapat mencontoh pilot plant yang telah beroperasi dengan baik di kantor kepala desa setempat.

Keberhasilan dalam menerapkan teknologi pengadaan air bersih ini sangat bergantung dari kondisi masyarakat desa. Jenis teknologi yang diterapkan, walaupun sudah menyentuh teknologi yang modern (pemanfaatan tenaga matahari), haruslah yang dapat diterima dan dimengerti oleh masyarakat. Jadi di dalam pemilihan teknologi pengadaan air bersih ini suatu hal yang sangat penting diperhatikan adalah kesesuaian dengan kondisi sosialekonomi masyarakat desa yang bersangkutan.

Berdasarkan wawancara dan pertemuanpertemuan dengan tokoh-tokoh masyarakat desa telah disepakati bahwa jenis pompa air baku yang disukai oleh orang-orang Desa Talang Alay, Padang Kuas dan Tebat Gunung adalah pompa tercelup (submersible pump), sementara itu untuk masyarakat Desa Maras Jauh, pompa air baku yang disukai adalah pompa listrik biasa yang diletakkan di permukaan tanah. Untuk sistem pengolahan air bakunya dipilih teknologi yang paling sederhana, yaitu proses penyaringan dengan menggunakan 5 jenis media penyaring. Media yang digunakan adalah kerikil besar, kerikil kecil, pasir silika, mangan zeolit dan karbon aktif.

\subsection{Program Penyediaan Air Bersih}

Pada program penyediaan air bersih ini, air baku berasal dari sumber air tanah yang seringkali banyak mengandung zat besi (Fe) dan mangan $(\mathrm{Mn})$. Adanya kandungan $\mathrm{Fe}$ dan $\mathrm{Mn}$ yang berlebih $(\mathrm{Fe}=1,7 \mathrm{ppm}$ dan $\mathrm{Mn}=0,7 \mathrm{ppm})$ dalam air akan menyebabkan warna air tersebut berubah menjadi kuning-kecoklatan setelah beberapa saat kontak dengan udara. Disamping dapat mengganggu kesehatan juga dapat menimbulkan bau yang kurang enak, serta menyebabkan warna kuning pada dinding bak dan bercak-bercak kuning pada pakaian. Banyak cara untuk menghilangkan zat besi dan mangan dalam air. Salah satu cara yang sederhana yaitu dengan cara menggabungkan proses aerasi dengan sistem penyaringan. Sesuai dengan kualitas air tanah yang akan diolah maka media filter yang digunakan, terdiri dari : kerikil, pasir silika, mangan zeolit dan karbon aktif, seperti terlihat pada gambar berikut.

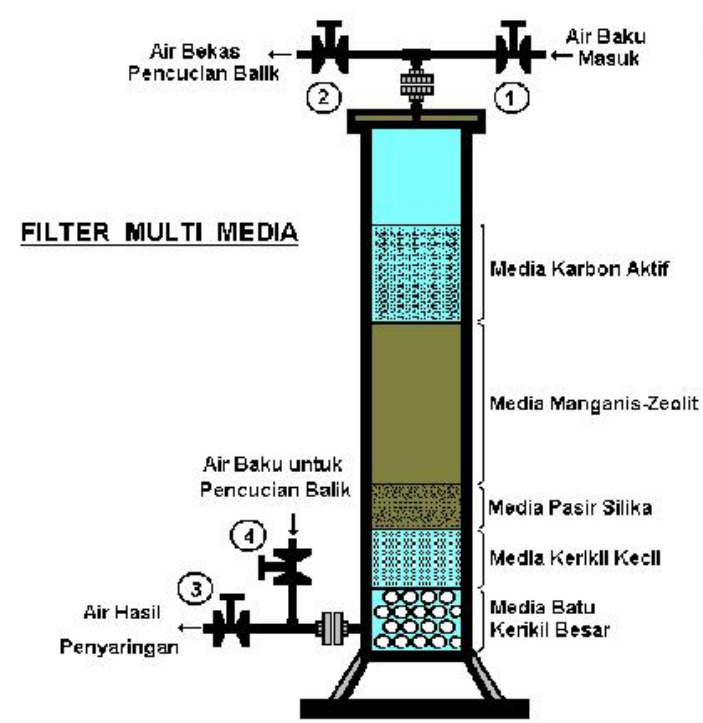

Gambar 1 : Filter Multi Media yang dioperasikan secara gravitasi.

Berhubung fasilitas listrik dari PLN (Perusahaan Listrik Negara) belum menjangkau keempat desa tersebut, maka sebagai tenaga penggerak dalam proses penyediaan air bersih ini, digunakan pompa yang memanfaatkan tenaga matahari, yaitu dengan memasang modul solar cell (sel surya) yang berfungsi sebagai alat pembangkit tenaga matahari untuk menggerakkan pompa tenaga surya yang dipasang pada sistem penyediaan air .

\section{PROSES PENGOLAHAN AIR}

\subsection{Proses Aerasi (Oksidasi Dengan Udara)}

Adanya kandungan alkalinity $\left(\mathrm{HCO}_{3}\right)^{-}$ yang cukup besar dalam air, akan menyebabkan 
senyawa besi atau mangan berada dalam bentuk senyawa ferro bikarbonat, $\mathrm{Fe}\left(\mathrm{HCO}_{3}\right)_{2}$ atau mangano bikarbonat, $\mathrm{Mn}\left(\mathrm{HCO}_{3}\right)_{2}$. Oleh karena bentuk $\mathrm{CO}_{2}$ bebas lebih stabil dari pada $\left(\mathrm{HCO}_{3}\right)^{-}$, maka senyawa bikarbonat cenderung berubah menjadi senyawa karbonat.

$$
\begin{aligned}
& \mathrm{Fe}\left(\mathrm{HCO}_{3}\right)_{2} \rightarrow \mathrm{FeCO}_{3}+\mathrm{CO}_{2}+\mathrm{H}_{2} \mathrm{O} \\
& \mathrm{Mn}\left(\mathrm{HCO}_{3}\right)_{2} \rightarrow \mathrm{MnCO}_{3}+\mathrm{CO}_{2}+\mathrm{H}_{2} \mathrm{O}
\end{aligned}
$$

Dari reaksi tersebut dapat dilihat, jika $\mathrm{CO}_{2}$ berkurang, maka kesetimbangan reaksi akan bergeser ke kanan dan selanjutnya reaksi akan menjadi sebagai berikut :

$$
\begin{aligned}
& \mathrm{FeCO}_{3}+\mathrm{H}_{2} \mathrm{O} \rightarrow \mathrm{Fe}(\mathrm{OH})_{2}+\mathrm{CO}_{2} \\
& \mathrm{MnCO}_{3}+\mathrm{H}_{2} \mathrm{O} \rightarrow \mathrm{Mn}(\mathrm{OH})_{2}+\mathrm{CO}_{2}
\end{aligned}
$$

Baik hidroksida besi (II) maupun hidroksida mangan (II) mempunyai kelarutan yang cukup besar, sehingga senyawa ini larut dalam air. Apabila dilakukan oksidasi dengan udara atau aerasi akan terjadi reaksi (ion) sebagai berikut :

$$
\begin{gathered}
4 \mathrm{Fe}^{2+}+\mathrm{O}_{2}+10 \mathrm{H}_{2} \mathrm{O} \rightarrow 4 \mathrm{Fe}(\mathrm{OH})_{3}+8 \mathrm{H}^{+} \\
2 \mathrm{Mn}^{2+}+\mathrm{O}_{2}+2 \mathrm{H}_{2} \mathrm{O} \rightarrow 2 \mathrm{MnO}_{2}+4 \mathrm{H}^{+}
\end{gathered}
$$

Sesuai dengan reaksi tersebut, maka untuk mengoksidasi setiap $1 \mathrm{mg} / \mathrm{l}$ zat besi dibutuhkan $0,14 \mathrm{mg} / \mathrm{l}$ oksigen dan setiap $1 \mathrm{mg} / \mathrm{l}$ mangan dibutuhkan 0,29 mg/l oksigen. Senyawasenyawa yang terbentuk ini kelarutannya sangat kecil, sehingga di dalam air berada dalam bentuk padatan. Oleh karena itu senyawa-senyawa ini dapat dipisahkan dari air.

Pada $\mathrm{pH}$ rendah, kecepatan reaksi oksidasi besi dengan oksigen (udara) relatif lambat, sehingga pada prakteknya untuk mempercepat reaksi dilakukan dengan cara menaikkan $\mathrm{pH}$ air yang akan diolah.

\subsection{Proses Dengan Mangan Zeolit}

Air baku yang mengandung besi dan mangan dialirkan melalui suatu filter bed yang media filternya terdiri dari mangan-zeolite $\left(\mathrm{K}_{2} \mathrm{Z} \cdot \mathrm{MnO} \cdot \mathrm{Mn}_{2} \mathrm{O}_{7}\right)$. Mangan Zeolit berfungsi sebagai katalis dan pada waktu yang bersamaan besi dan mangan yang ada dalam air teroksidasi menjadi bentuk ferri-oksida dan mangan-dioksida yang tak larut dalam air.

Reaksinya adalah sebagai berikut :

$\mathrm{K}_{2} \mathrm{Z} \cdot \mathrm{MnO} \cdot \mathrm{Mn}_{2} \mathrm{O}_{7}+4 \mathrm{Fe}\left(\mathrm{HCO}_{3}\right)_{2} \rightarrow$ $\mathrm{K}_{2} \mathrm{Z}+3 \mathrm{MnO}_{2}+2 \mathrm{Fe}_{2} \mathrm{O}_{3}+8 \mathrm{CO}_{2}+4 \mathrm{H}_{2} \mathrm{O}$

$$
\begin{aligned}
& \mathrm{K}_{2} \mathrm{Z} \cdot \mathrm{MnO} \cdot \mathrm{Mn}_{2} \mathrm{O}_{7}+ 2 \mathrm{Mn}\left(\mathrm{HCO}_{3}\right)_{2} \rightarrow \\
& \mathrm{K}_{2} \mathrm{Z}+5 \mathrm{MnO}_{2}+4 \mathrm{CO}_{2}+2 \mathrm{H}_{2} \mathrm{O}
\end{aligned}
$$

Reaksi penghilangan besi dan mangan dengan mangan zeolite tidak sama dengan proses pertukaran ion, tetapi merupakan reaksi dari $\mathrm{Fe}^{2+}$ dan $\mathrm{Mn}^{2+}$ dengan oksida mangan tinggi (higher mangan oxide).

Filtrat yang terjadi mengandung mengandung ferri-oksida dan mangan-dioksida yang tak larut dalam air, sehingga dapat dipisahkan dengan pengendapan dan penyaringan. Selama proses berlangsung kemampunan reaksinya makin lama makin berkurang dan akhirnya menjadi jenuh. Untuk regenerasinya dapat dilakukan dengan menambahkan larutan Kalium Permanganat ke dalam zeolite yang telah jenuh tersebut, sehingga akan terbentuk lagi mangan zeolite $\left(\mathrm{K}_{2} \mathrm{Z} . \mathrm{MnO} \cdot \mathrm{Mn}_{2} \mathrm{O}_{7}\right.$ ).

\subsection{Proses Pengolahan Air Dengan Aerasi Dan Filtrasi}

Pada proses penjernihan ini, pertamatama air dialirkan dari sumur ke tempat penampungan air (lihat Gambar 2). Saat air masuk ke dalam tangki penampung air baku, pada bagian ujung pipa yang masuk ke dalam tangki dibuat sedemikian rupa (berlubanglubang), sehingga air baku akan tersebar atau seperti terdispersi. Disini air kontak dengan udara, sehingga terjadi proses aerasi. Besi dan mangan mulai teroksidasi dan kemudian terbentuk senyawa yang tak larut dalam air. Selanjutnya air dialirkan ke dalam filter yang berisi beberapa lapisan media dengan urutan dari atas ke bawah sebagai berikut : arang aktif, mangan zeolit, pasir silika dan kerikil. Lapisan arang aktif berfungsi untuk menghilangkan bau yang disebabkan senyawa-senyawa organik yang kadangkala terdapat dalam air. Senyawasenyawa organik ini diadsorpsi oleh pori-pori arang aktif. Pada lapisan mangan zeolit kembali terbentuk padatan dari senyawa besi dan mangan, sehingga padatan ini dapat tersaring pada lapisan pasir silika dan kerikil. Air yang keluar dari filter akan berupa air yang jernih yang bebas dari bau, senyawa besi dan mangan serta zat-zat tersuspensi lainnya. Air ini belum bisa langsung diminum karena kemungkinan masih mengandung bakteri-bakteri yang tidak dapat tersaring oleh pasir silika, maka untuk dapat diminum harus didesinfeksi, misalnya dengan direbus dahulu sampai mendidih atau dengan menggunakan sinar ultra violet. 


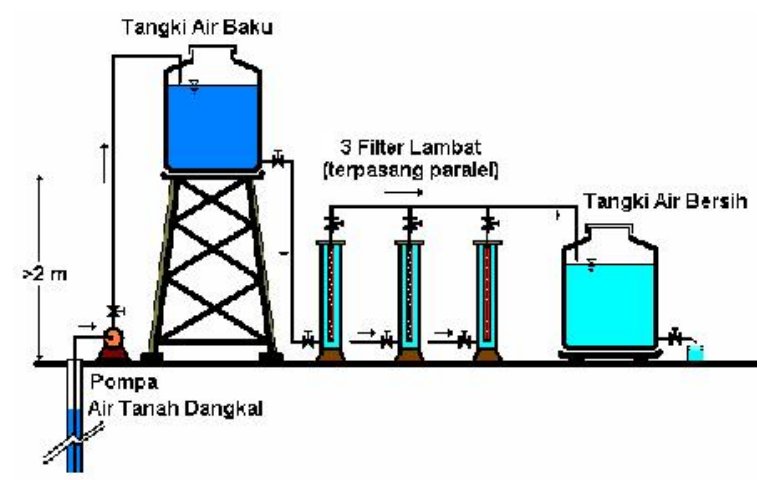

Gambar 2 : Rangkaian Proses Pengolahan Air.

\section{CARA KERJA UNIT PENGOLAHAN AIR}

\subsection{Pengangkatan Air}

Air dari sumur dinaikkan ke dalam bak penampung dengan menggunakan pompa submersibel atau pompa air tanah dangkal yang digerakkan oleh tenaga matahari (Gambar 2).

Tabel 1: Spesifikasi teknik pompa.

\begin{tabular}{|c|c|}
\hline Nomor Model & 9325-043-101 \\
\hline Disain Pompa & $\begin{array}{l}\text { Positive Displacement } 3 \\
\text { Chamber Diaphragm Pump }\end{array}$ \\
\hline Cam & 3,0 degree \\
\hline Motor & $\begin{array}{l}\text { Permanent Magnet, } \mathrm{P} / \mathrm{N} 11- \\
175-00 . \text { Thermally Protected }\end{array}$ \\
\hline Voltage & 24 V DC Nominal \\
\hline AMPS & 4,0 Maksimum \\
\hline Internal Bypass & $\begin{array}{l}\text { 105-110 PSI Maks. }(7,2-7,5 \\
\text { Bar) }\end{array}$ \\
\hline $\begin{array}{l}\text { Daya Dorong } \\
\text { Pengangkatan } \\
\text { Maks. }\end{array}$ & 230 Feet Max. (70 meter) \\
\hline $\begin{array}{l}\text { Maksimum } \\
\text { Pencelupan }\end{array}$ & 100 Feet Max. (30 meter) \\
\hline Bagian Outlet & $\begin{array}{l}1 / 2 \text { " (12,7 mm) Barbed Fitting } \\
\text { for } 1 / 2 \text { " I.D Tubing }\end{array}$ \\
\hline Bagian Inlet & $\begin{array}{l}\text { Saringan Stainless Steel } 50 \\
\text { Mesh }\end{array}$ \\
\hline Material Bahan & $\begin{array}{l}\text { High Strength Engineered } \\
\text { Plastic, Stainless Steel } \\
\text { Fasteners. }\end{array}$ \\
\hline $\begin{array}{l}\text { Kegunaan } \\
\text { Khusus }\end{array}$ & $\begin{array}{l}\text { Potable water Well Pump } \\
\text { (Pompa Sumur Air Minum) }\end{array}$ \\
\hline Berat Bersih & 6 LBS. $(2,7 \mathrm{Kg})$ \\
\hline
\end{tabular}

Model pompa submersibel yang digunakan adalah "Solarex/SHURflo Solar Submersible Pumping Systems", tipe HF2 package, tipe ini mempunyai maksimum pengangkatan setinggi 70 meter dan kapasitas maksimum pengaliran adalah 440 liter per jam (lihat Tabel 1 dan 2).
Tabel 2 : Kapasitas pengangkatan air dari pompa SHURflo Model 9300

\begin{tabular}{|c|c|}
\hline $\begin{array}{c}\text { Total Kapasitas } \\
\text { Pengangkatan (Meter) }\end{array}$ & $\begin{array}{c}\text { Laju Alir } \\
\text { (Liter/Jam) }\end{array}$ \\
\hline 6,1 & 440 \\
\hline 12,2 & 432 \\
\hline 18,3 & 413 \\
\hline 24,4 & 401 \\
\hline 30,5 & 390 \\
\hline 36,6 & 382 \\
\hline 42,7 & 375 \\
\hline 48,3 & 371 \\
\hline 54,9 & 352 \\
\hline 61,0 & 345 \\
\hline 70,1 & 310 \\
\hline
\end{tabular}

Seperti telah disebutkan di atas, sumber tenaga penggerak pompa adalah tenaga matahari. Adapun perangkat tenaga matahari yang dipasang terdiri dari Modul Surya, Controller dan Assesoris. Jenis modul surya yang digunakan adalah model MSX-60 Photovoltaic Modules. Untuk menjalankan pompa dipasang 2 buah modul yang masing-masing mempunyai berat 15,9 pounds $(7,2 \mathrm{Kg})$ dengan dimensi $93,7 \mathrm{~cm} \times 50 \mathrm{~cm}$ (lihat Tabel 3).

Tabel 3 : Karakteristik modul model MSX-60.

\begin{tabular}{|l|c|}
\hline Typical Peak power (Pp) & $60 \mathrm{Watt}$ \\
\hline Voltage peak power (Vpp) & $17,4 \mathrm{~V}$ \\
\hline Current peak power (Ipp) & $3,5 \mathrm{~A}$ \\
\hline $\begin{array}{l}\text { Guaranteed minimum peak } \\
\text { power }\end{array}$ & $58 \mathrm{Watt}$ \\
\hline Short circuit current (Isc) & $3,8 \mathrm{~A}$ \\
\hline Open circuit voltage (Voc) & $21,3 \mathrm{~V}$ \\
\hline $\begin{array}{l}\text { Temperature coefficient of } \\
\text { open-circuit voltage }\end{array}$ & $-73 \mathrm{mV} /{ }^{\circ} \mathrm{C}$ \\
\hline $\begin{array}{l}\text { Temperature coefficient of } \\
\text { short circuit current }\end{array}$ & $3 \mathrm{~mA} /{ }^{\circ} \mathrm{C}$ \\
\hline $\begin{array}{l}\text { Approximate effect of } \\
\text { temperature on power }\end{array}$ & $-0,38 \% /{ }^{\circ} \mathrm{C}$ \\
\hline $\begin{array}{l}\text { NOTC (Nominal Operating } \\
\text { Cell Temperature) }\end{array}$ & $49{ }^{\circ} \mathrm{C}$ \\
\hline
\end{tabular}

\subsection{Pengoperasian Filter Multi Media}

Pada saat penjernihan/penyaringan, air dialirkan dari atas ke bawah, sementara pada saat pencucian air dialirkan dari bawah ke atas. Untuk saringan tipe 1 (lihat Gambar 1):

Cara kerja penyaringan:

1. Kran 1 dan 3 dibuka.

2. Kran 2 dan 4 ditutup.

Cara kerja pencucian :

1. Kran 2 dan 4 dibuka.

2. Kran 1 dan 3 ditutup. 


\subsection{Perawatan Sistem Penyediaan Air}

\subsubsection{Perawatan Modul Sel Surya}

Pada modul sel surya yang perlu diperhatikan adalah permukaan modul berupa kaca yang merupakan bagian yang mentransmisikan (melewatkan) cahaya matahari ke dalam sel surya. Untuk itu kebersihannya perlu dijaga, agar cahaya matahari dapat menembus permukaan ini dengan baik. Perawatan yang dilakukan adalah pembersihan permukaan Modul Surya (kaca) setiap 4 bulan, dengan menggunakan lapisan pembersih (deterjen) dan menggunakan kain halus.

\subsubsection{Perawatan Pompa}

Agar pompa dapat selalu mengalirkan air dengan lancar, maka yang perlu dilakukan adalah memeriksa filter pompa secara rutin dan kemudian membersihkannya dari kotoran-kotoran yang menempel. Perlu diperhatikan pula laju alir air yang dihasilkan, apabila terjadi penurunan maka kemungkinan terjadi penyumbatan pada filter.

\subsubsection{Perawatan Filter}

Dalam perawatan filter, yang paling penting adalah melakukan pencucian secara teratur, paling sedikit 1 kali dalam seminggu, lebih sering akan lebih baik lagi. Apabila jarang dilakukan pencucian, maka selain mempengaruhi kualitas air hasil penyaringan, dapat pula mempercepat proses pengerakan endapan pada media filter, terutama pada media pasir silica. Hal ini dapat mengakibatkan filter tidak berfungsi dengan baik dan akan mempercepat proses penggantian media filter.

Penggantian filter pada umumnya dilakukan setelah lama pemakaian antara 1 sampai 2 tahun. Untuk media kerikil ada kemungkinan dapat digunakan kembali setelah dicuci dengan bersih, bahan-bahan media filter lainnya dapat diperoleh di pasaran yang ada di tempat-tempat tertentu .

\section{PENUTUP}

Penyediaan air bersih dengan sistem yang sederhana dan dengan memanfaatkan tenaga matahari sebagai sumber energi, merupakan suatu program yang tepat untuk diterapkan di daerah-daerah pedesaan yang masih belum mendapat fasilitas listrik dari PLN, serta yang tingkat sosial ekonomi masyarakatnya masih rendah. Namun suatu hal yang perlu diperhatikan agar program dapat selalu berjalan dengan baik adalah aspek sosial masyarakat pemakai yang dalam hal ini perlu sekali ditanamkan kesadaran kepada masyarakat tentang pentingnya kebersihan yang berdampak langsung terhadap kesehatan, baik terhadap individu maupun terhadap lingkungan. Dengan adanya kesadaran dari masyarakat pemakai, maka pemeliharaan peralatan sistem penyediaan air bersih yang telah dibangun akan terlaksana dengan baik. Dengan demikian kelangsungan penyediaan air bersih akan dapat terus berjalan, sehingga akhirnya masyarakat akan lebih terjamin untuk dapat hidup sehat dan sejahtera.

\section{DAFTAR PUSTAKA}

1. Japan Waterworks Association, "Design Criteria For Waterworks Facilities", 1978.

2. Fair,G.M.,Geyer J.C, and Okun,D.A., "Elements of Water Supply and Waste Water Disposal", Second Edition, John Wiley and Sons, New York, 1971.

3. Hamer,M.J., "Water and Waste Water Technology",Second Edition, John Wiley and Sons, New York, 1986.

4. Nusa I.S., "Metoda Penghilangan Zat Besi dan Mangan di dalam Penyediaan Air Minum Domestik", Jurnal Air Indonesia, Vol. 1, No. 3, Jakarta, Desember 2005. 